\title{
INDIVIDUAL AND EQUITOXIC EFFECTS OF COPPER AND CADMIUM ON BEHAVIOURAL RESPONSES AND SURVIVAL IN CARP, LABEO ROHITA (HAMILTON, 1822)
}

\author{
R. Niranjani, S. Rani Jeyamary* and R. James \\ Department of Zoology, V.O.Chidambaram College**, \\ Tuticorin - 628008, TN, India \\ * Department of Chemistry, St. Mary's College**, Tuticorin - 628001, TN, India \\ ** Affiliated to ManonmaniamSundaranar University, Abishekapatti, Tirunelveli - 627012, Tamil Nadu, India.
}

\begin{abstract}
Acute toxicity of copper, cadmium individually and in combinations of $\mathrm{Cu}+\mathrm{Cd}$ were studied in carp, Labeorohitaas a function of time. Mortality of fish was dependent on dose of metal exposures and exposure period. The behavioural changes of $L$. rohitawere found to be different when exposed to $\mathrm{Cu}$ and $\mathrm{Cd}$ individually and in combinations. It was more pronounced in test animals exposed to equitoxic levels of $\mathrm{Cu}+\mathrm{Cd}$ followed by individual exposures of $\mathrm{Cu}$ and $\mathrm{Cd}$, while it was completely absent in the control fish. The $96 \mathrm{hr}$ median lethal concentration of copper, cadmium and combination of both in L. rohitawas $0.42,0.78$ and $0.39 \mathrm{ppm}$ respectively. Similar trend was observed in 24,48 and $72 \mathrm{hrs}$ also. It manifests that $\mathrm{Cu}+\mathrm{Cd}$ combination was more toxic than any one of the single metal solutions tested.
\end{abstract}

KEYWORDS: Heavy metals, $\mathrm{Cu}+\mathrm{Cd}$, survival, behavioural changes, additive effect, Labeorohita.

\section{INTRODUCTION}

The effect of heavy metals on aquatic organisms is currently attracting widespread attention, particularly in studies related to industrial pollution ${ }^{19}$. Indiscriminate discharge of raw and partially treated industrial effluents into aquatic system leads to deterioration of the environment. Various metals are present in industrial effluents in significant quantities and they usually occur as components of metal mixtures. Biological effects of heavy metal mixtures in aquatic environment is highly complicated due to interactions between them ${ }^{24,14}$. Copper and cadmium occur simultaneously in the environment and are toxic to fish ${ }^{9,14}$. The combined effects of metals may be different from individual effect when many metals are present in a system simultaneously.
Many authors have studied the toxic effects of individual heavy metals on fish ${ }^{\mathbf{3 , 8 , 1 5}}$; however, the deleterious effects of metal mixtures on aquatic organisms are largely unknown $^{16,14,9}$. Hence, the present study has been undertaken to study the toxic effects of copper and cadmium individually and equitoxic or combinations of both on behavioural responses and survival in carp, Labeorohita at different time.

\section{MATERIALS AND METHODS}

Experimental fish Labeorohitawere collected from Rajan Fish Farm, Vellanguli, Tirunelveli district, Tamil Nadu. They were acclimatized to ambient laboratory conditions for 3 weeks. The water was changed daily and fish were fed ad libitum with pelletized diet containing $35 \%$ protein. 
The water used was clean and unchlorinated. Static renewable bioassay method ${ }^{23}$ was adopted to determine the $\mathrm{LC}_{50}$ values at different hours $(24,48,72$ and 96) for the chosen metals $\mathrm{Cu}$ and $\mathrm{Cd}$ individually and also for their combinations. Stock solutions of copper and cadmium were separately prepared by dissolving $3.93 \mathrm{~g}$ of Analar grade $\mathrm{CuSO}_{4} 5 \mathrm{H}_{2} \mathrm{O}$ (MERCK) and $6.84 \mathrm{~g}$ of $\mathrm{CdSO}_{4} 4 \mathrm{H}_{2} \mathrm{O}$ in $1 l$ of distilled water and then diluted with fresh water to obtain the desired concentrations. For metal combinations, equal amount of respective metal stock solutions were taken and dissolved in the medium.

Nine hundred and eighty $(1.80 \pm 0.18 \mathrm{~g})$ healthy individuals of $L$. rohitawere selected from the acclimation tanks for the bio-assay experiment. To determine the $\mathrm{LC}_{50}$ values of $L$. rohitaagainst copper toxicity, the stock fish were divided into 11 groups of 10 individuals each and exposed to the toxic concentrations of copper $(0.05,0.1,0.2,0.3$, $0.4,0.6,0.7,0.8,1.0,1.2$ and $1.4 \mathrm{ppm})$. Similarly, another 11 groups of $L$. rohita were exposed to toxic concentrations of cadmium $(0.2,0.3,0.4,0.6,0.8,1.0,1.2$, $1.4,1.6,1.8,2.0 \mathrm{ppm}$ ) and also another 11 groups exposed to equitoxic levels of $\mathrm{Cu}$ and $\mathrm{Cd}(0.28,0.30,0.32,0.34,0.38,0.42$, $0.46,0.50,0.60,0.80 \mathrm{ppm})$ separately for $96 \mathrm{hrs}$. One day prior to the experiment and throughout the bio-assay test the fish were starved. The experiment was conducted incircular plastic trough containing $10 l$ of freshwater with various toxic concentrations of chosen metals. The medium was changed daily to maintain constant toxic concentrations of metals ${ }^{22}$. Salinity, temperature, $\mathrm{pH}$ and dissolved oxygen content of tested media averaged to $0.20 \%$, $28.6^{\circ} \mathrm{C}, 7.65$ and $5.40 \mathrm{mlO}_{2} l^{-1}$ respectively. Control group was also maintained in metal free-water. Mortality was recorded at every $1 \mathrm{hr}$ intervals upto $24 \mathrm{hr}, 3 \mathrm{hr}$ intervals upto $48 \mathrm{hr}$ and $6 \mathrm{hr}$ intervals upto $96 \mathrm{hr}$. Probit analysis was followed for the calculation of $\mathrm{LC}_{50}$ values at $24,48,72$ and $96 \mathrm{hrs}$, its $95 \%$ confidence limits and slope function $(\mathrm{s})^{18}$.

\section{RESULTS AND DISCUSSION}

\section{Behavioural changes}

The behavioural changes of L. rohita were found to be different when exposed to $\mathrm{Cu}$ and $\mathrm{Cd}$ individually and in combinations. When test animals were exposed to chosen tested media, L. rohita showed an avoidance response even at low concentrations. At lethal concentrations, they tried to avoid the toxicant by irregular erratic swimming, jerky movements, rapid opercular movements, restlessness, frequent surfacing (3-5 times/ $\min$ in $\mathrm{Cu}+\mathrm{Cd}$ exposure), upside down surface movement (2, 3 and 5 times / min in $\mathrm{Cd}, \mathrm{Cu}$ and $\mathrm{Cu}+\mathrm{Cd}$ exposures). Finally they lost their equilibrium and settled at the bottom before death. The dead animals showed blood clots on the gill surface and widely opened mouth and gills. It was more pronounced in test animals exposed to equitoxic levels of $\mathrm{Cu}+\mathrm{Cd}$ followed by individual exposures of $\mathrm{Cu}$ and $\mathrm{Cd}$, while it was completely absent in the control fish. 
The observation showed that mortality of L. rohitadependent on the concentrations of chosen heavy metals and duration of the exposure i.e., time and dose-dependent responses.

Heavy metals in general cause inhibition of mitochondrial enzymes ${ }^{6}$ and ATP ase ${ }^{4}$ resulting the decline of cellular respiration and death of animals ${ }^{1}$. L. rohita showed rapid movement initially when exposed to tested concentrations and a subsequent reduction in these activities while increasing the concentrations or the exposure duration. The hyperactivity in the initial period indicates an escape behavior of the fish due to metal stress ${ }^{7}$. Moreover, a concentration and duration based reduction in these activities were a sign of physiological adjustment ${ }^{25}$. The present study reveals that, the secretion of mucous was regarded as a defense and excretory response ${ }^{2}$, which might help in protecting gills and skin from heavy metal toxicity. The erratic swimming and upside down movement of heavy metals exposed fish indicates that, the region in the brain which is associated with maintenance of equilibrium should have been affected under the metal toxicity?

The peculiar behavior of fish at surface was more frequent in L. rohita exposed to $\mathrm{Cu}+\mathrm{Cd}\left(9-12\right.$ times min $\left.^{-1}\right)$ combination followed by $\mathrm{Cu}\left(7-9\right.$ times $\left.\min ^{-1}\right)$ and $\mathrm{Cd}$ $\left(3-5\right.$ times $\left.\mathrm{min}^{-1}\right)$ exposures. The increase in occurrence of tested fish at surface might either be due to difficulty to respire in the medium or hypoxic condition in the medium. Rao and $\mathrm{Rao}^{21}$ reported that pesticide exposed air-breathing fish Channa punctatus exhibited the more frequent surface frequency to carbaryl + phenthoate combination $\left(5-8\right.$ times $\left.\mathrm{min}^{-1}\right)$ followed by phenthoate $\left(4-6\right.$ times $\min ^{-1}$ ) and carbaryl ( $3-5$ times $\left.\mathrm{min}^{-1}\right)$, which supports the observation made in the present study. Comparatively, metal exposed L. rohita showed more occurrence at the surface as compared to surfacing frequency of pesticide exposed $C$. punctatus and it may be due to the following reasons: (i) less tolerance to metals toxicity and (ii) absence of air-breathing organs to hold more oxygen. The toxicant either metal or pesticide are known to inhibit acetylcholinesterase, a neurotransmitter enzyme and cause hyper excitability $^{\mathbf{2 0}}$, which inturn might also influence behavior patterns. Though the behavioural patterns mostly neurological, are also influenced by other metabolic changes, the sum total of all these neurological, physiological and biochemical changes at the tissue level contributes to the abnormal behavior of the fish which is greater under $\mathrm{Cu}+\mathrm{Cd}$ combination than under individual exposures. This shows that $\mathrm{Cu}+\mathrm{Cd}$ combination has an additive effect on the morphological conditions, behavior patterns and survival of the fish. In a way, the abnormal behavior exhibited by the fish can be taken as a useful parameter in assessing the extent of metal stress, because, the fish serves as a bio-indicator of aquatic pollution. Thus, behavioural studies need much emphasis in understanding changes 
in the animal habitat, because an altered environmental condition manifests stress on the animal.

\section{Survival}

The bioassay result revealed that, the mortality of $L$. rohita dependent on the concentrations of copper and cadmium individually and in combinations and the duration of exposure. The $\mathrm{LC}_{50}$ values of $L$. rohita exposed to $\mathrm{Cu}$ or $\mathrm{Cd}$ individually at 24, 48, 72 and $96 \mathrm{hrs}$ were 0.70 or 1.34 , 0.50 or $1.06,0.43$ or 0.84 and 0.42 or 0.78 ppm (Table 1 and 2) respectively. The low $\mathrm{LC}_{50}$ values in copper exposed fish showed that, copper was more toxic than cadmium. The $\mathrm{LC}_{50}$ values of $L$. rohitaexposed to equitoxic of $\mathrm{Cu}+\mathrm{Cd}$ were $0.45,0.41,0.40$ and $0.39 \mathrm{ppm}$ at 24, 48, 72 and $96 \mathrm{hrs}$ respectively (Table 3 ). These values were close to $\mathrm{LC}_{50}$ values of $\mathrm{Cu}(0.70,0.50,0.43$ and $0.42 \mathrm{ppm}$ at 24, 48, 72 and $96 \mathrm{hrs}$ ) as compared to $\mathrm{LC}_{50}$ values of $\mathrm{Cd}(1.34,1.06$, 0.84 and $0.78 \mathrm{ppm}$ at $24,48,72$ and $96 \mathrm{hrs}$ ) (Table 1 and 2). The regression equations obtained for $96 \mathrm{hr} \mathrm{LC}_{50}$ values of $\mathrm{Cu}, \mathrm{Cd}$ and $\mathrm{Cu}+\mathrm{Cd}$ exposures were $\mathrm{Y}=3.89+$ $127.33 \mathrm{x}, \mathrm{Y}=2.75+67.45 \mathrm{x}$ and $\mathrm{Y}=121.27$ $+440.91 \mathrm{x}$ (Figures $1-3$ ) respectively. The 'b' value obtained for $\mathrm{Cu}+\mathrm{Cd}$ toxicity was 440.91 and it declined to 127.33 in $\mathrm{Cu}$ and 67.45 in Cd (Figures 3, 1 and 2) exposures which evidently confirmed that the combined effect of $\mathrm{Cu}+\mathrm{Cd}$ was more toxic than the individual effect of $\mathrm{Cu}$ and $\mathrm{Cd}$. The toxic nature of tested exposures occurred in the following order : $\mathrm{Cu}+\mathrm{Cd}$ $>\mathrm{Cu}>\mathrm{Cd}$.
In accordance with the present study, time-and concentrations dependent mortality was observed in Channa punctatus exposed to different concentrations of mercuric chloride ${ }^{1}$. A gradual decrease in the $\mathrm{LC}_{50}$ values of $\mathrm{Cu}$ and $\mathrm{Cd}$ individually and in combinations was observed due to extensions of exposure period. Similar observation was made in Heteropneustes fossilis exposed to carbaryl ${ }^{25}$, and Oreochromis mossambicus exposed to endosulfan ${ }^{5}$, supports the present study.In the present investigation, the $96 \mathrm{hr} \mathrm{LC}_{50}$ values of copper and cadmium were found to be 0.42 and $0.78 \mathrm{ppm}$ in L. rohita. It shows that $\mathrm{Cu}$ was more toxic nature than Cd.James and Sampath ${ }^{\mathbf{1 0}}$ observed that, the $96 \mathrm{hr} \mathrm{LC}_{50}$ value of copper reported for Heteropneustes fossilis was $2.4 \mathrm{ppm}$ and $4.27 \mathrm{ppm}$ in $O$. mossambicus $^{13}$. Vijayram et $a l .{ }^{26}$ reported that, the $96 \mathrm{hr} \mathrm{LC}_{50}$ value of cadmium was $5.6 \mathrm{ppm}$ in Anabas testudineus. The $96 \mathrm{hr} \mathrm{LC}_{50}$ value of cadmium reported for $H$. fossilis was $15 \mathrm{ppm}^{\mathbf{1 1}}$ and $12 \mathrm{ppm}$ in O. mossambicus ${ }^{\mathbf{1 2}}$. The data obtained in the present investigation indicates that different fishes have different tolerance range against the toxicity of the same metals.

The $96 \mathrm{hr}$ median lethal concentration of copper, cadmium and combination of both in L. rohita was $0.42,0.78$ and $0.39 \mathrm{ppm}$ respectively. Similarly, the $96 \mathrm{hr} \mathrm{LC}_{50}$ value of copper, cadmium and combination of both in O.mossambicus was 2.01, 16.71 and 1.79 ppm respectively ${ }^{14}$. It manifests that $\mathrm{Cu}+$ $\mathrm{Cd}$ combination was more toxic than any 
Table 1. Effect of toxic concentrations of copper on per cent mortality in Labeo rohitaexposed for different hours. Lethal concentrations, slope function and $95 \%$ confidence limits are expressed in ppm

\begin{tabular}{|c|c|c|c|c|c|c|c|c|c|}
\hline \multirow[t]{2}{*}{$\begin{array}{c}\text { Duration } \\
\text { (hrs.) }\end{array}$} & \multirow[t]{2}{*}{\begin{tabular}{|c|}
$\begin{array}{c}\text { Concentrations } \\
(\mathrm{ppm})\end{array}$ \\
\end{tabular}} & \multirow[t]{2}{*}{$\begin{array}{l}\text { Dead / } \\
\text { Tested }\end{array}$} & \multirow[t]{2}{*}{$\begin{array}{c}\text { Mortality } \\
(\%)\end{array}$} & \multicolumn{3}{|c|}{$\begin{array}{l}\text { Lethal concentrations at } \\
(\mathrm{ppm})\end{array}$} & \multirow[t]{2}{*}{$\begin{array}{c}\text { Slope } \\
\text { function }\end{array}$} & \multicolumn{2}{|c|}{$\begin{array}{l}\text { 95\% confidence } \\
\text { limit }\end{array}$} \\
\hline & & & & $16 \%$ & $50 \%$ & $84 \%$ & & $\begin{array}{c}\text { Lower } \\
\text { limit }\end{array}$ & $\begin{array}{c}\text { Upper } \\
\text { limit }\end{array}$ \\
\hline 24 & $\begin{array}{l}0.8 \\
0.3 \\
0.4 \\
0.6 \\
0.7 \\
0.8 \\
1.0 \\
1.2 \\
1.4\end{array}$ & $\begin{array}{c}0 / 10 \\
2 / 10 \\
4 / 10 \\
4 / 10 \\
5 / 10 \\
6 / 10 \\
6 / 10 \\
9 / 10 \\
10 / 10\end{array}$ & $\begin{array}{c}0 \\
20 \\
40 \\
40 \\
50 \\
60 \\
60 \\
90 \\
100\end{array}$ & 0.27 & 0.70 & 1.13 & 2.10 & 0.57 & 0.84 \\
\hline 48 & $\begin{array}{l}0.2 \\
0.3 \\
0.4 \\
0.6 \\
0.7 \\
0.8 \\
1.0\end{array}$ & $\begin{array}{c}0 / 10 \\
3 / 10 \\
4 / 10 \\
6 / 10 \\
8 / 10 \\
9 / 10 \\
10 / 10\end{array}$ & $\begin{array}{c}0 \\
30 \\
40 \\
60 \\
80 \\
90 \\
100\end{array}$ & 0.26 & 0.50 & 0.73 & 1.69 & 0.41 & 0.58 \\
\hline 72 & $\begin{array}{c}0.05 \\
0.1 \\
0.2 \\
0.3 \\
0.4 \\
0.6 \\
0.7 \\
0.8\end{array}$ & $\begin{array}{l}0 / 10 \\
1 / 10 \\
1 / 10 \\
3 / 10 \\
6 / 10 \\
7 / 10 \\
8 / 10 \\
9 / 10\end{array}$ & $\begin{array}{c}0 \\
10 \\
10 \\
30 \\
60 \\
70 \\
80 \\
100\end{array}$ & 0.20 & 0.43 & 0.66 & 1.62 & 0.36 & 0.51 \\
\hline 96 & $\begin{array}{c}0.05 \\
0.1 \\
0.2 \\
0.3 \\
0.4 \\
0.6 \\
0.7 \\
0.8\end{array}$ & $\begin{array}{c}0 / 10 \\
1 / 10 \\
2 / 10 \\
3 / 10 \\
6 / 10 \\
7 / 10 \\
8 / 10 \\
10 / 10\end{array}$ & $\begin{array}{c}0 \\
10 \\
20 \\
30 \\
60 \\
70 \\
80 \\
100\end{array}$ & 0.18 & 0.42 & 0.67 & 1.96 & 0.35 & 0.50 \\
\hline
\end{tabular}

48 • J. Adv. Zool. $2020: 41(1 \& 2)$ 
Table 2. Effect of toxic concentrations of cadmium on per cent mortality in Labeo rohitaexposed for different hours. Lethal concentrations, slope function and $95 \%$ confidence limits are expressed in ppm

\begin{tabular}{|c|c|c|c|c|c|c|c|c|c|}
\hline \multirow[t]{2}{*}{$\begin{array}{l}\text { Duration } \\
\text { (hrs.) }\end{array}$} & \multirow[t]{2}{*}{$\begin{array}{c}\text { Concentrations } \\
(\mathrm{ppm})\end{array}$} & \multirow[t]{2}{*}{$\begin{array}{l}\text { Dead / } \\
\text { Tested }\end{array}$} & \multirow[t]{2}{*}{$\begin{array}{c}\text { Mortality } \\
(\%)\end{array}$} & \multicolumn{3}{|c|}{$\begin{array}{l}\text { Lethal concentrations at } \\
(\mathrm{ppm})\end{array}$} & \multirow[t]{2}{*}{$\begin{array}{c}\text { Slope } \\
\text { function }\end{array}$} & \multicolumn{2}{|c|}{$\begin{array}{l}\text { 95\% confidence } \\
\text { limit }\end{array}$} \\
\hline & & & & $16 \%$ & $50 \%$ & $84 \%$ & & $\begin{array}{c}\text { Lower } \\
\text { limit }\end{array}$ & $\begin{array}{c}\text { Upper } \\
\text { limit }\end{array}$ \\
\hline 24 & $\begin{array}{l}0.8 \\
1.0 \\
1.2 \\
1.4 \\
1.6 \\
1.8 \\
2.0\end{array}$ & $\begin{array}{c}0 / 10 \\
2 / 10 \\
4 / 10 \\
6 / 10 \\
7 / 10 \\
9 / 10 \\
10 / 10\end{array}$ & $\begin{array}{c}0 \\
20 \\
40 \\
60 \\
70 \\
90 \\
100\end{array}$ & 1.00 & 1.34 & 1.68 & 1.29 & 1.24 & 1.44 \\
\hline 48 & $\begin{array}{l}0.4 \\
0.6 \\
0.8 \\
1.0 \\
1.2 \\
1.4 \\
1.6 \\
1.8\end{array}$ & $\begin{array}{c}0 / 10 \\
2 / 10 \\
3 / 10 \\
4 / 10 \\
7 / 10 \\
8 / 10 \\
8 / 10 \\
10 / 10\end{array}$ & $\begin{array}{c}0 \\
20 \\
30 \\
40 \\
70 \\
80 \\
80 \\
100\end{array}$ & 0.62 & 1.06 & 1.50 & 1.55 & 0.93 & 0.18 \\
\hline 72 & $\begin{array}{l}0.2 \\
0.3 \\
0.4 \\
0.6 \\
0.8 \\
1.0 \\
1.2 \\
1.4 \\
1.6\end{array}$ & $\begin{array}{c}0 / 10 \\
1 / 10 \\
2 / 10 \\
4 / 10 \\
5 / 10 \\
6 / 10 \\
7 / 10 \\
9 / 10 \\
10 / 10\end{array}$ & $\begin{array}{c}0 \\
10 \\
20 \\
40 \\
50 \\
60 \\
70 \\
90 \\
100\end{array}$ & 0.39 & 0.84 & 1.28 & 1.83 & 0.74 & 0.94 \\
\hline 96 & $\begin{array}{l}0.1 \\
0.2 \\
0.3 \\
0.4 \\
0.6 \\
0.8 \\
1.0 \\
1.2 \\
1.4\end{array}$ & $\begin{array}{c}0 / 10 \\
1 / 10 \\
2 / 10 \\
3 / 10 \\
4 / 10 \\
5 / 10 \\
6 / 10 \\
7 / 10 \\
10 / 10\end{array}$ & $\begin{array}{c}0 \\
10 \\
20 \\
30 \\
40 \\
50 \\
60 \\
70 \\
100\end{array}$ & 0.29 & 0.78 & 1.27 & 1.20 & 0.66 & 0.93 \\
\hline
\end{tabular}

$49 ・ J$. Adv. Zool. $2020: 41(1 \& 2)$ 
Table 3. Combined toxic effects of copper and cadmium on per cent mortality in Labeo rohitaexposed for different hours. Lethal concentrations, slope function and $95 \%$ confidence limits are expressed in ppm

\begin{tabular}{|c|c|c|c|c|c|c|c|c|c|}
\hline \multirow[t]{2}{*}{$\begin{array}{c}\text { Duration } \\
\text { (hrs.) }\end{array}$} & \multirow[t]{2}{*}{$\begin{array}{c}\text { Concentrations } \\
(\mathrm{ppm})\end{array}$} & \multirow[t]{2}{*}{$\begin{array}{l}\text { Dead / } \\
\text { Tested }\end{array}$} & \multirow[t]{2}{*}{$\begin{array}{c}\text { Mortality } \\
(\%)\end{array}$} & \multicolumn{3}{|c|}{$\begin{array}{l}\text { Lethal concentrations at } \\
(\mathrm{ppm})\end{array}$} & \multirow[t]{2}{*}{$\begin{array}{c}\text { Slope } \\
\text { function }\end{array}$} & \multicolumn{2}{|c|}{$\begin{array}{l}\text { 95\% confidence } \\
\text { limit }\end{array}$} \\
\hline & & & & $16 \%$ & $50 \%$ & $84 \%$ & & $\begin{array}{l}\text { Lower } \\
\text { limit }\end{array}$ & $\begin{array}{l}\text { Upper } \\
\text { limit }\end{array}$ \\
\hline 24 & $\begin{array}{l}0.34 \\
0.36 \\
0.38 \\
0.42 \\
0.46 \\
0.50 \\
0.60 \\
0.80\end{array}$ & $\begin{array}{c}0 / 10 \\
2 / 10 \\
3 / 10 \\
4 / 10 \\
5 / 10 \\
8 / 10 \\
9 / 10 \\
10 / 10\end{array}$ & $\begin{array}{c}0 \\
20 \\
30 \\
40 \\
50 \\
80 \\
90 \\
100\end{array}$ & 0.35 & 0.45 & 0.54 & 1.24 & 0.42 & 0.48 \\
\hline 48 & $\begin{array}{l}0.32 \\
0.34 \\
0.36 \\
0.38 \\
0.42 \\
0.46 \\
0.50 \\
0.60\end{array}$ & $\begin{array}{c}0 / 10 \\
1 / 10 \\
3 / 10 \\
4 / 10 \\
5 / 10 \\
7 / 10 \\
9 / 10 \\
10 / 10\end{array}$ & $\begin{array}{c}0 \\
10 \\
30 \\
40 \\
50 \\
70 \\
90 \\
100\end{array}$ & 0.35 & 0.41 & 0.48 & 1.17 & 0.40 & 0.43 \\
\hline 72 & $\begin{array}{l}0.30 \\
0.32 \\
0.34 \\
0.36 \\
0.38 \\
0.42 \\
0.46 \\
0.50\end{array}$ & $\begin{array}{c}0 / 10 \\
1 / 10 \\
2 / 10 \\
3 / 10 \\
4 / 10 \\
5 / 10 \\
7 / 10 \\
10 / 10\end{array}$ & $\begin{array}{c}0 \\
10 \\
20 \\
30 \\
40 \\
50 \\
70 \\
100\end{array}$ & 0.34 & 0.40 & 0.47 & 1.17 & 0.39 & 0.43 \\
\hline 96 & $\begin{array}{l}0.28 \\
0.30 \\
0.32 \\
0.34 \\
0.36 \\
0.38 \\
0.42 \\
0.46 \\
0.50\end{array}$ & $\begin{array}{c}0 / 10 \\
1 / 10 \\
2 / 10 \\
3 / 10 \\
4 / 10 \\
5 / 10 \\
6 / 10 \\
8 / 10 \\
10 / 10\end{array}$ & $\begin{array}{c}0 \\
10 \\
20 \\
30 \\
40 \\
50 \\
60 \\
80 \\
100\end{array}$ & 0.32 & 0.39 & 0.46 & 1.20 & 0.37 & 0.40 \\
\hline
\end{tabular}

$50 \bullet J$. Adv. Zool. $2020: 41(1 \& 2)$ 
Figure 1. Effect of toxic concentrations of copper on per cent mortality in Labeo rohitaexposed for different hours

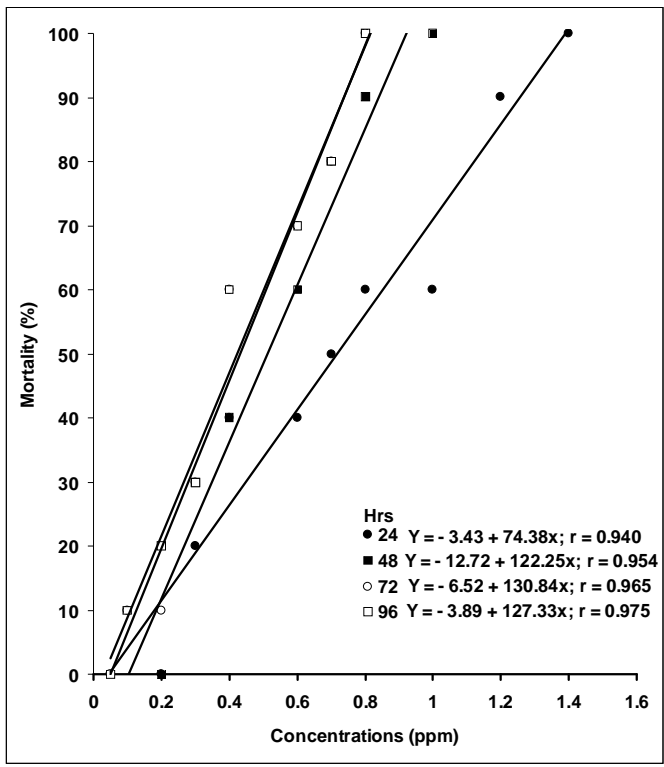

Figure 2. Effect of toxic concentrations of cadmium on per cent mortality in Labeo rohitaexposed for different hours

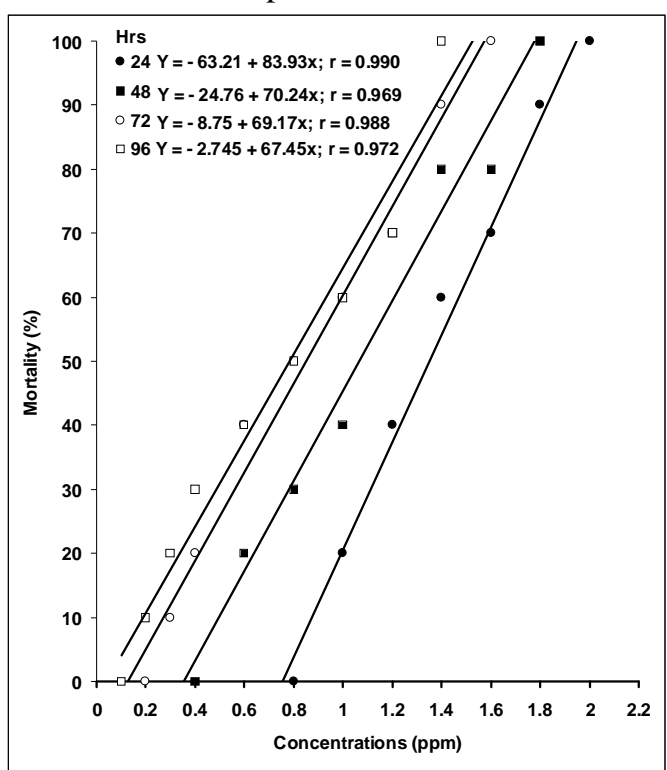

Figure 3. Combined toxic effects of copper and cadmium on per cent mortality in Labeo rohitaexposed for different hours

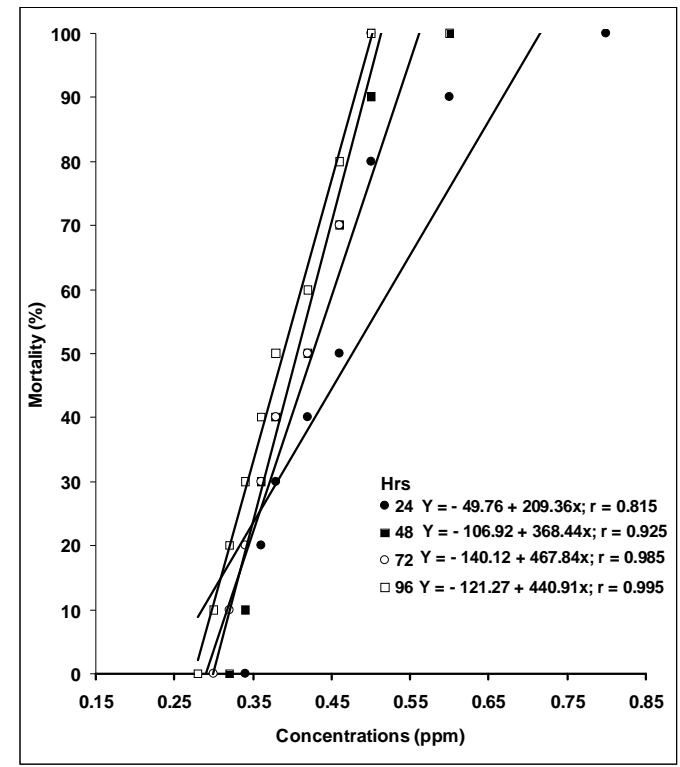

one of the single metal solutions tested. Working on Clariasbatrachus, Katti and Sathyanesan ${ }^{16}$ found that $\mathrm{Pb}+\mathrm{Cd}$ treated fish showed a significant high mortality and weight reduction as compared to those treated with $\mathrm{Pb}$ or $\mathrm{Cd}$ alone. Lewis ${ }^{17}$ found that $\mathrm{Cu}+\mathrm{Zn}$ was the most lethal toxicant and exhibited a more than additive toxicity as compared to the additive toxicity of $\mathrm{Cu}$ $+\mathrm{Mn}$ mixtures in juvenile longfin dace, Agosiachrysogaster.

\section{CONCLUSION}

In the present study, the ' $b$ ' values 127 , 67 and 441 arrived from regression equations of $96 \mathrm{hr} \mathrm{LC}_{50}$ values in $\mathrm{Cu}$ and $\mathrm{Cd}$ exposures individually and combination of both in L. rohita. It revealed that copper 
was highly toxic to that of cadmium and its combinations was extremely toxic nature as compared to its individual toxicity.

\section{REFERENCES}

1. Agarwal, S.K., 1991. Bioassay evaluation of acute toxicity levels of mercuric chloride to air breathing fishes Channa punctatus (Bloch): mortality and behavioural study. Journal of Environmental Biology, 12: 99 106.

2. Bennett, R.O. and J.K. Dooley, 1982. Copper intake by two sympatric species of Fundulusheteroclitusand F. majalis (Walbann). J. Fish. Biol., 21: 381-398.

3. Collvin, L., 1985. The effect of copper on growth, food consumption and food conversion of perch Percaflavitilis offered maximal food rations. Aquatic toxicology, 5: 105-113.

4. Farmanfarmaian, A., R. Socci and T. Polidore, 1980. Mechanism of heavy metal inhibition of amino acid transport in the intestine of marine fishes, Bulletin Marine Biology, pp. $159,458$.

5. Ganesan, R.M., S.R.D. Jebakumar and J. Jeyaraman, 1989. Sub-lethal effects of organochlorine insecticide (endosulfan) on protein, carbohydrate and lipid contents on liver tissues of Oreochromis mossambicus. Proceedings of Indian Academy of Sciences, 98: 51-55.

6. Hingorani, H.G., A.D. Diwan and N.C.K. Naidu, 1973. Oxygen consumption in the fish Labeorohitaduring expanses to different concentrations of industrial effluents. Compasitive Physiology and Ecology, 4: 272 $-276$.

7. James, R., 1990. Individual and combined effects of heavy metals on behavior and respiratory responses on Oreochromis mossambicus. Indian Journal of Fisheries, 37: 139 - 143.

8. James, R., 2000. Effect of EDTA on reduction of cadmium level in water and improvement of growth in Oreochromis mossambicus. J. Аqua. Trop., $15: 23-33$.

9. James, R., 2011. Effect of dietary selenium supplementation on Cirrhinusmrigala (Hamilton, 1822) reared in copper and cadmium contaminated water. Israeli $J$. Aquaculture, 63: 573-579.

10. James, R. and K. Sampath, 1995. Sublethal effects of mixtures of copper and ammonia on selected biochemical and physiological parameters in the catfish, Heteropneustes fossilis (Bloch). Bull. Environ. Contamn. Toxicol., 55: 187-194.

11. James, R. and K. Sampath, 1999a. Effect of zeolite on reduction of cadmium toxicity: An experimental study on element uptake and growth in Heteropneustes fossilis (Bloch). $J$. Aqua. Trop., 14 : 65-74.

12. James, R. and K. Sampath, 1999b. Effect of zeolite on the reduction of cadmium toxicity in water and in a fresh water fish, Oreochromis mossambicus. Bull. Environ. Contamn. Toxicol., 62: 222-229.

13. James, R. and K. Sampath, 2003. Removal of copper toxicity by zeolite in Java Tilapia, Oreochromis mossambicus. Bull. Environ. Contamn. Toxicol.,71: 1184-1191.

14. James, R., K. Sampath and K. Punithavathi Ponmani, 1992. Effect of metal mixtures on activity of two respiratory enzymes and their recovery in Oreochromis mossambicus (Peters). Indian J. Expt. Biol., 30: 496-499.

15. James, R., K. Sampath and D.S. Edward, 2003. Copper toxicity on growth and reproductive potential in an aquarium fish, Xiphophorus helleri. Asian Fisheries Science, 16: 317-326.

16. Katti, S.R. and A.G. Sathyanesan, 1984. Effects of lead, cadmium and combination of both on the ascorbic acid content of the brain and ovary of the fish Clariasbatrachus. Environ. Ecol., 2: 296 - 299.

17. Lewis, M., 1978. Acute toxicity of copper, zinc and manganese in single and mixed salt solutions to juvenile longfin dace, Agosiachrysogaster. J. Fish. Biol., 13: 695 - 
700.

18. Litchfield, J.T.Jr. and F. Wilcoxon, 1949. A simplified method of evaluating dose effect experiments. Pharmacol J. Exp. Thero., 96: $99-113$.

19. Menezes, M.R. and S.Z. Qasim, 1983. Determination of acute toxicity levels of mercury to the fish Tilapia mossambica (Peters). Proc. Indian Acad. Sci., (Anim. Sci.), 92(5): $375-380$.

20. O'Brien, R.D., 1976. Acetylcholinesterase and its inhibition. In C.F. Wilkinson (ed.). Insecticide Bio-Chemistry and Physiology. Plenum Press, New York, pp. 271 - 286.

21. Rao, K.R.S. and J. Rao, 1987. Independent and combined action of carbaryl and phenthoate on snake head, Channa punctatus (Bloch). Current Science., 56(7): 331 - 332.

22. Sprague, J.B., 1971. Measurement of pollutant toxicity to fish. III. Sublethal effects and safe concentrations. Water Res., 3: 793-821.
23. Sprague, J.B., 1973. The ABC's of pollutant bioassay using fish. In: Biological Methods for the Assessment of Water Quality. STP 528, Am. Soc. Testing Materials.

24. Stebbing, A.P.R. and V.J.R.S. Fantino, 1983. The combined and separate effects of copper and cadmium on the growth of Campanulariaflexuosacolonies (Hydrazua). Aquatic Toxicology, 3: 189 - 193.

25. Verma, S.R., S.K. Bansal, A.K.Gupta, N. Pal, A.C. Tyagi, M.C. Bhatnagar, K. Kumar and R.C. Dalela, 1979. Acute toxicity of three pesticides to a fresh water teleost, Saccobranchus fossilis. Proc. Symp. Environ. Biol., (Eds. Verma, S.R., A.K. Tyagi \& S.K. Bansal). The Academy of Environmental Biology Muzaffarnagar, India, pp. 481 - 497.

26. Vijayram, K., K. Geraldene, T.S.Varadarjan, J. George and P. Loganathan, 1989. Cadmium induced changes in the biochemistry of an air-breathing fish (Anabas testudineus). Journal of Ecobiology, 1: 245 - 251. 